\title{
CONF-950894--1
}

\section{Intermetallic Bonded Ceramic Matrix Composites}

\author{
K.P. Plucknett, T.N. Tiegs, K.B. Alexander, P.F. Becher, J.H. Schneibel, S.B. Waters and P.A. Menchhofer \\ Metals and Ceramics Division, Oak Ridge National Lab., P.O. Box 2008, Oak Ridge, TN 37831, USA.
}

\begin{abstract}
A range of carbide- and oxide-based cermets have been developed utilizing ductile nickel aluminide $\left(\mathrm{Ni}_{3} \mathrm{Al}\right)$ alloy binder phases. Some of these, notably materials based upon tungsten and titanium carbides (WC and TiC respectively), offer potential as alternatives to the cermets which use cobalt binders (i.e. WC/Co). Samples have been prepared by blending commercially available $\mathrm{Ni}_{3} \mathrm{Al}$ alloy powders with the desired ceramic phases, followed by hot-pressing. Alumina $\left(\mathrm{Al}_{2} \mathrm{O}_{3}\right)$ matrix materials have also been prepared by pressurized molten alloy infiltration. The microstructure, flexure strength and fracture toughness of selected materials will be discussed.
\end{abstract}

\section{DISCLAIMER}

This report was prepared as an account of work sponsored by an agency of the United States Government. Neither the United States Government nor any agency thereof, nor any of their employees, makes any warranty, express or implied, or assumes any legal liability or responsibility for the accuracy, completeness, or usefulness of any information, apparatus, product, or process disclosed, or represents that its use would not infringe privately owned rights. Reference herein to any specific commercial product, process, or service by trade name, trademark, manufacturer, or otherwise does not necessarily constitute or imply its endorsement, recomand opinions favoring by the United States Government or any agency thereof. The views and opinions of authors expressed herein do not necessarily state or reflect those of the United States Government or any agency thereof. 


\section{DISCLAIMER}

Portions of this document may be illegible in electronic image products. Images are produced from the best available original document. 


\section{INTRODUCTION}

Hardmetal or cemented carbide materials such as tungsten carbide/cobalt (WC/Co) have reached a considerable degree of property refinement, achieved through continuous development for the last seventy years (1-3). These materials offer a unique combination of mechanical properties, as summarized in Table I, and consequently they have found a large number of applications. Examples of these include; cutting tools, drilling bits, wire drawing dies, punch/die sets, spray and blast nozzles, aluminum/plastic extrusion dies etc. (4). Although the mechanisms controlling the fracture behavior are not fully understood, several recent studies have addressed this problem more thoroughly (5-7).

Table I - Mechanical properties of WC/Co hard metals for three different Co contents (summarized from data presented in ref. 2).

\begin{tabular}{llll}
\hline \hline Co content, wt. \% (vol. \%) & $5(8.5)$ & $15(23.7)$ & $25(37)$ \\
\hline Vickers hardness & $1400-1800$ & $1100-1450$ & $700-1100$ \\
Comp. strength (MPa) & $5600-6100$ & $4300-4900$ & $3200-3700$ \\
Trans. rupture strength $(\mathrm{MPa})$ & $1800-2800$ & $2600-3200$ & $2900-3300$ \\
Fracture toughness $\left(\mathrm{MPa} . \mathrm{m}^{1 / 2}\right)$ & $8-10$ & $15-17.5$ & $18-22$ \\
\hline \hline
\end{tabular}

The use of cobalt as the binder phase presents several problems. In particular cobalt is rare, and consequently expensive, and it also has poor resistance to corrosion in aqueous and acidic environments. Several examinations into alternative binder phases for WC cermets have been performed (8-12). Holleck (8) and Prakash et al (9) have demonstrated that iron and/or nickel, with small additions of cobalt, can be used as binders giving comparable properties to cobalt binders. A mixed Ni-Al binder system was examined by Viswanadham et al (10), where the Al content in the binder was varied between 4 and $12 \mathrm{wt} . \%$. In this system attempts were made to 'harden' the binder phase by in-situ precipitation of the $\gamma^{\prime} \mathrm{Ni}_{3} \mathrm{Al}$ phase, with mixed results (10). More recently, Faroog and Davies (11,12) have demonstrated that WC cemented with ferro-alloys (i.e. stainless steel or $\mathrm{Fe}-\mathrm{Co}-\mathrm{NiMoB}$ ) also offer potential for replacement of WC/Co.

In the present study a range of carbide and oxide based hardmetal/cermet systems have been investigated, using ductile $\mathrm{Ni}_{3} \mathrm{Al}$ binder phases as replacements for $\mathrm{Co}$. $\mathrm{Ni}_{3} \mathrm{Al}$ binders have been selected due their improved corrosion resistance relative to $\mathrm{Co}$. They also exhibit good high temperature (i.e. up to $800^{\circ} \mathrm{C}$ ) strength retention compared to $\mathrm{Co}$. This initial report focuses upon materials densified by uniaxial hot-pressing, however the authors have recently demonstrated that carbide based systems can also be prepared to high sintered densities ( $>97 \%$ of theoretical) by conventional vacuum sintering techniques (13). In addition alumina $\left(\mathrm{Al}_{2} \mathrm{O}_{3}\right)$ matrix cermets have been assessed. which were prepared by pressurized melt infiltration of $\mathrm{Ni}_{3} \mathrm{Al}$.

\section{EXPERIMENTAL TECHNIQUES}

Several $\mathrm{Ni}_{3} \mathrm{Al}$ alloys (supplied by Homogenous Metals, Clayville, N.Y.) have been utilized in the present study, and the compositions of those used for cermet fabrication are summarized in Table II. The $\mathrm{Ni}_{3} \mathrm{Al}$ alloys were classified to $-325 \mathrm{mesh}(<44 \mu \mathrm{m})$. Various carbide and oxide powders have been used, and these are summarized in Table III. Powder mixtures have been prepared by ball milling in non aqueous medium (iso-propanol or hexane), for up to 24 hours. After milling the mixtures were dried, crushed and hot-pressed in graphite dies. Carbide based materials were hot-pressed between 1150 and $1450^{\circ} \mathrm{C}$, wheras temperatures between 1300 and $1550^{\circ} \mathrm{C}$ were used for the oxide-based materials. Samples were hot-pressed at pressures up to $34 \mathrm{MPa}$, for between 15 and 120 minutes, in $0.1 \mathrm{MPa}$ Argon. Wetting studies have been performed on hot-pressed or pressureless-sintered substrates of each of the 'pure' ceramics; several other $\mathrm{Ni}_{3} \mathrm{Al}$ alloys have been used for the wetting studies. These were conducted using the sessile drop technique at $1450^{\circ} \mathrm{C}$ in vacuum $\left(\sim 10^{-4} \mathrm{~Pa}\right)$, with samples held at temperature for 15 minutes. In addition to the hot-pressed materials, $\mathrm{Al}_{2} \mathrm{O}_{3} / \mathrm{Ni} 3 \mathrm{Al}$ cermets have been prepared by pressure infiltration of pre-sintered $\mathrm{Al}_{2} \mathrm{O}_{3}$ preforms at the Technische Universität, Hamburg-Harburg, Germany. The infiltrated $\mathrm{Al}_{2} \mathrm{O}_{3} / \mathrm{Ni}_{3} \mathrm{Al}$ cermets were prepared by immersing the preform into the molten alloy (at $1650^{\circ} \mathrm{C}$ ), and subsequently pressurizing the furnace to $\sim 17 \mathrm{MPa}$, after which the infiltrated body is extracted from the molten alloy and cooled (14). 
Table II - The compositions (in wt. \%) of $\mathrm{Ni}_{3} \mathrm{Al}$ alloys used for cermet fabrication in the present work.

\begin{tabular}{llllll}
\hline \hline Alloy & Aluminum & Boron & Zirconium & Chromium & Nickel \\
\hline IC-15 & 12.7 & 0.05 & 0 & 0 & Balance \\
IC-50 & 11.3 & 0.02 & 0.6 & 0 & Balance \\
IC-218 & 8.5 & 0.02 & 0.8 & 7.8 & Balance \\
\hline \hline
\end{tabular}

Table III - Ceramic powders used in the present study.

\begin{tabular}{lll}
\hline \hline Powder & Supplier/Grade & Average Dia. $(\mu \mathrm{m})$ \\
\hline Tungsten carbide (WC) & Kennametal/WCA-20 & 2.5 \\
Titanium carbide (TiC) & Kennametal/TICA-3 & 1.3 \\
Alumina & Sumitomo/AKP-30 & 0.5 \\
\hline \hline
\end{tabular}

Densities have been determined by the Archimedes method, via immersion in distilled water. The microstructures of dense materials have been assessed by scanning and transmission electron microscopy (SEM and TEM respectively), both with energy dispersive X-ray (EDX) analysis capabilities. Flexural strength has been measured in four-point bend, with $20 \mathrm{~mm}$ inner and $40 \mathrm{~mm}$ outer spans, using test bars 3 $\times 4 \times 50 \mathrm{~mm}$. Fracture toughness has been assessed by both the indentation (15), indentation/fracture (16) and chevron notch techniques. Additionally, a few samples have been tested in-situ within the SEM to determine ' $R$ '-curve behavior, using a four-point flexure straining stage. The corrosion resistance of selected materials has been measured by immersion in $10 \%$ acid solutions for a period of $48 \mathrm{~h}$. Comparison has been made with data obtained at the same time on commercial grade WC/Co materials.

\section{RESULTS AND DISCUSSION}

The wetting angle for combinations of several ceramic substrates and $\mathrm{Ni}_{3} \mathrm{Al}$ alloys are shown in Table IV. It is apparent that the wetting angles for $\mathrm{Ni}_{3} \mathrm{Al}$ on various non-oxide substrates are low, typically less than $20^{\circ}$. Conversely, the wetting angle on the oxide substrates are high, generally greater than $70^{\circ}$, and often above $90^{\circ}$. It is important to note that for 'ease' of processing a low wetting angle is desirable. Figure la shows the cross section of an $\mathrm{Ni} 3 \mathrm{Al}$ (IC-50 alloy) sessile drop on $\mathrm{TiC}$ after heating to $1550^{\circ} \mathrm{C}$. The low wetting angle previously noted is clearly shown. SEM examination of the interface between the $\mathrm{Ni}_{3} \mathrm{Al}$ and $\mathrm{TiC}$ demonstrates the absence of any reaction phases, however grain boundary penetration by the molten $\mathrm{Ni} 3 \mathrm{Al}$ alloy is apparent (Figure $1 \mathrm{~b}$ ). The lack of interfacial reaction products in the $\mathrm{Ni} 3 \mathrm{Al} / \mathrm{TiC}$ wetting studies confirms previous observations on this system (17). Conversely, interfacial reactions have been noted in the $\mathrm{Ni}_{3} \mathrm{Al} / \mathrm{TiB} \mathrm{B}_{2}$ system $(18,19)$. For the case of $\mathrm{Ni}_{3} \mathrm{Al}$ and $\mathrm{Al}_{2} \mathrm{O}_{3}$ in combination, $\mathrm{ZrO}_{2}$ precipitates have been noted to form at the interface between the two phases, for the cases where $\mathrm{Zr}$ is present in the $\mathrm{Ni}_{3} \mathrm{Al}$ alloy $(20-23)$.

It is apparent from SEM examination of the microstructures of the hot-pressed $\mathrm{Ni}_{3} \mathrm{Al}$ containing cermets, that the wetting characteristics previousiy described have a strong influence upon the morphological evolution of the microstructure. Figure $2 \mathrm{a}$ demonstrates the formation of discrete islands of $\mathrm{Ni} 3 \mathrm{Al}$ in the $\mathrm{Al}_{2} \mathrm{O}_{3}$ based composites, indicating that densification is dominated by solid state sintering of the $\mathrm{Al}_{2} \mathrm{O}_{3}$ matrix (24). These materials were hot-pressed below the melting temperature of $\mathrm{Ni}_{3} \mathrm{Al}$, which is approximately $1390-1400^{\circ} \mathrm{C}$, in order to prevent the non-wetting aluminide phase being exuded from the sample during hot-pressing.

Conversely the carbide matrix materials exhibited a semi-continuous $\mathrm{Ni} 3 \mathrm{Al}$-based grain boundary phase (Figure 2b). The 'apparent' intergranular liquid volume is lower than the overall Ni3 $\mathrm{Al}$ content in these materials due to the retention of isolated large $\mathrm{Ni3} A \mathrm{Al}$ regions after hot-pressing (Figure $2 \mathrm{~b}$ ). This indicates that the coarse $\mathrm{Ni}_{3} \mathrm{Al}$ powders $(-325 \mathrm{mesh},<44 \mu \mathrm{m})$ are not significantly reduced in size during wet milling. Recently a small batch of $-10 \mu \mathrm{m} \mathrm{Ni} 3 \mathrm{Al}$ powder (IC-50 alloy) has been provided by $\mathrm{X}$-form Ltd. (Cohoes, N.Y.), and the effects of substitution of this powder for the coarse Ni3Al is the subject of 
current investigations. The effective reduction in the $\mathrm{Ni}_{3} \mathrm{Al}$ volume (due to the retention of isolated $\mathrm{Ni}_{3} \mathrm{Al}$ islands) results in a high percentage of WC/WC grain boundaries, similar in appearance to low cobalt content WC/Co hardmetals. It is likely that these WC/WC boundaries undergo solid state sintering during hot-pressing, although high resolution electron microscopy would be required to confirm the absence of $\mathrm{Ni}_{3} \mathrm{Al}$ at these grain boundaries. It was also apparent that a small volume of $\mathrm{Al}_{2} \mathrm{O}_{3}$ particles were formed during hot-pressing, presumably arising from oxygen 'pick-up' during wet milling (i.e. by partial oxidation of the $\mathrm{Ni}_{3} \mathrm{Al}$ powder). These sub-micron $\mathrm{Al}_{2} \mathrm{O}_{3}$ grains were concentrated at the edge of the large $\mathrm{Ni}_{3} \mathrm{Al}$ rich regions. EDX analysis of the $\mathrm{Ni}_{3} \mathrm{Al}$ binder demonstrated that $\mathrm{W}$ dissolution into this phase had occurred during hot-pressing (and also Ti dissolution in the TiC-based materials). This is to be expected based upon the observations of Ochiai et al (25) and Liu and Stiegler (26). Ti is known to substitute primarily onto $\mathrm{Al}$ sites in $\mathrm{Ni}_{3} \mathrm{Al}$ (25), unlike other metals such as $\mathrm{Fe}$, Mo and W which substitute onto both $\mathrm{Ni}$ and $\mathrm{Al}$ sites in the $\mathrm{Ni} 3 \mathrm{Al}$ lattice (25.26). The solubility of $\mathrm{W}$ in $\mathrm{Ni}_{3} \mathrm{Al}$ was observed to be lower than that of $\mathrm{Ti}$, in accordance with previous work $(25,26)$.

Table IV - The wetting behavior of several $\mathrm{Ni}_{3} \mathrm{Al}$ alloy/ceramic substrate combinations.

\begin{tabular}{lcc}
\hline \hline Alloy Composition (at. \%) & Substrate Material & Wetting Angle (deg.) \\
\hline $\mathrm{Ni}-22 \mathrm{Al}-1 \mathrm{Zr}-0.1 \mathrm{~B}$ & $\mathrm{Al}_{2} \mathrm{O}_{3}$ & $>90$ \\
$\mathrm{Ni}-16 \mathrm{Al}-8 \mathrm{Cr}-1 \mathrm{Zr}-0.1 \mathrm{~B}$ & $\mathrm{Al}_{2} \mathrm{O}_{3}$ & $>90$ \\
$\mathrm{Ni}-23 \mathrm{Al}-1 \mathrm{C}-0.1 \mathrm{~B}$ & $\mathrm{Al}_{2} \mathrm{O}_{3}$ & 76 \\
$\mathrm{Ni}-22 \mathrm{Al}-1 \mathrm{Zr}-0.1 \mathrm{C}-0.1 \mathrm{~B}$ & $\mathrm{Al}_{2} \mathrm{O}_{3}$ & 77 \\
$\mathrm{Ni}-22 \mathrm{Al}-1 \mathrm{Zr}-0.1 \mathrm{C}-0.1 \mathrm{~B}$ & $\mathrm{Al}_{6} \mathrm{Si}_{2} \mathrm{O}_{13}$ & 90 \\
$\mathrm{Ni}-22 \mathrm{Al}-1 \mathrm{Zr}-0.1 \mathrm{C}-0.1 \mathrm{~B}$ & $\mathrm{ZrO}_{2}\left(2.5 \mathrm{~mol}_{2} \mathrm{Y}_{2} \mathrm{O}_{3}\right)$ & 76 \\
$\mathrm{Ni}-22 \mathrm{Al}-1 \mathrm{Zr}-0.1 \mathrm{C}-0.1 \mathrm{~B}$ & $\mathrm{TiC}$ & $10-20$ \\
$\mathrm{Ni}-22 \mathrm{Al}-1 \mathrm{Zr}-0.1 \mathrm{C}-0.1 \mathrm{~B}$ & $\mathrm{TiB}$ & 20 \\
\hline \hline
\end{tabular}
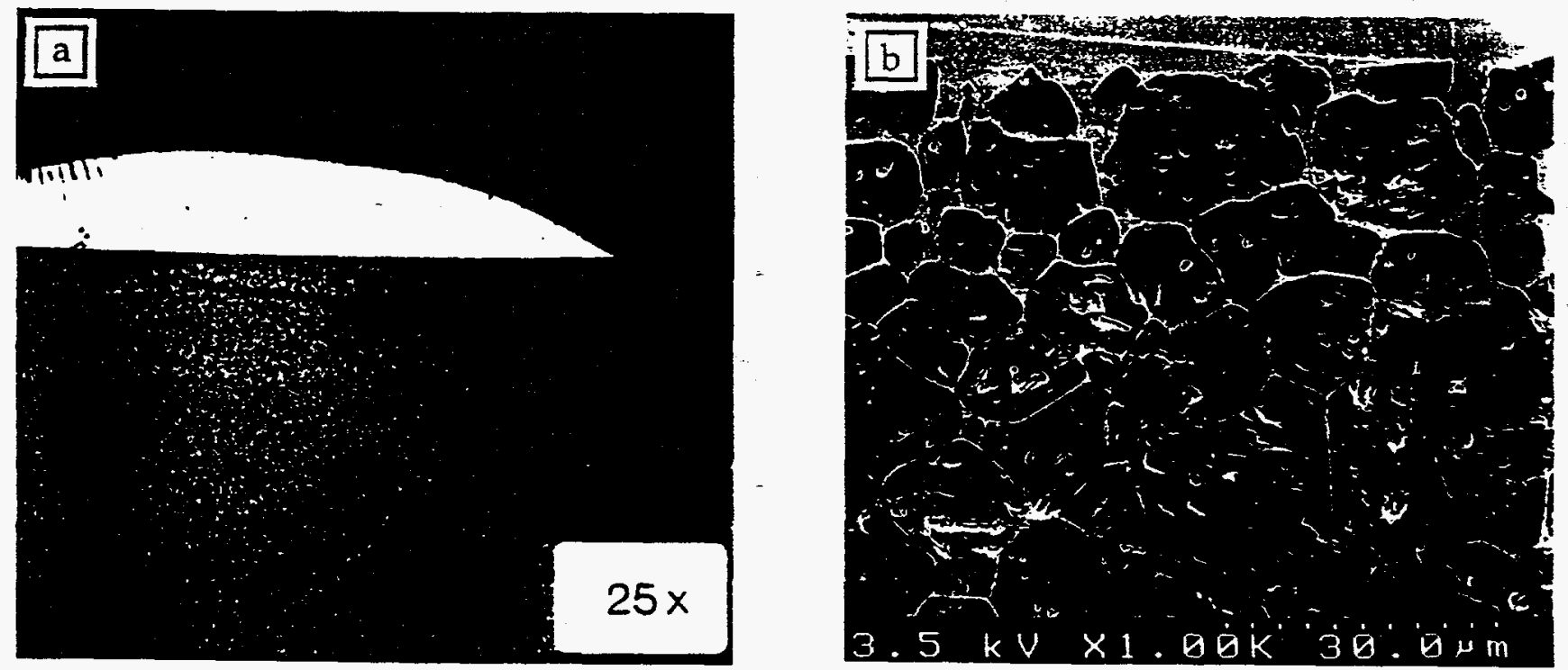

Figure 1 - (a) Optical micrograph demonstrating the wetting of $\mathrm{TiC}$ by a $\mathrm{Ni}_{3} \mathrm{Al}$ alloy. (b) SEM micrograph of the interface between the $\mathrm{TiC}$ and $\mathrm{Ni}_{3} \mathrm{Al}$. showing grain boundary penetration.

Room temperature properties of some of the carbide and oxide matrix composites fabricated with $\mathrm{Ni}_{3} \mathrm{Al}$ additions (IC-50 alloy) are shown in Table V. Although the observed properties are not as high as those observed for WC/Co cermets (Table I), it is important to note that those materials have benefited from over 70 years of continuous development. The WC/68 vol. \% Ni3 Al cermets produced in the present study exhibit an impressive combination of high strength and toughness. with reasonable hardness (Table $\mathrm{V})$. Both the WC and TiC cermets prepared with 17 vol. \% Ni3Al exhibit flexure strengths comparable to hardmetals prepared with $\mathrm{Ni}$ binders (27), while observed toughness values are similar to those for hardmetals prepared with Co binders (see Table I and references $2,3,5,6$ ). 
Table V - Summary of the mechanical properties of selected $\mathrm{Ni}_{3} \mathrm{Al}$ containing cermets.

\begin{tabular}{llll}
\hline \hline $\begin{array}{l}\text { Composition } \\
\text { Volume \%) }\end{array}$ & $\begin{array}{l}\text { Microhardness } \\
(\mathrm{GPa})\end{array}$ & $\begin{array}{l}\text { RT Flexure Strength } \\
(\mathrm{MPa})\end{array}$ & $\begin{array}{l}\text { RT Fracture Toughness } \\
\left(\mathrm{MPa} \cdot \mathrm{m}^{1 / 2}\right)\end{array}$ \\
\hline $\mathrm{WC}-17 \mathrm{Ni}_{3} \mathrm{Al}$ & $14-18$ & $1200-1350$ & $10-20$ \\
$\mathrm{WC}-68 \mathrm{Ni}_{3} \mathrm{Al}$ & 7 & 1750 & 25 \\
$\mathrm{TiC}-17 \mathrm{Ni}_{3} \mathrm{Al}$ & $16-20$ & $750-900$ & $8-14$ \\
$\mathrm{Al}_{2} \mathrm{O}_{3}-10 \mathrm{Ni} \mathrm{Al}$ & 14 & 550 & $7-8$ \\
\hline \hline
\end{tabular}
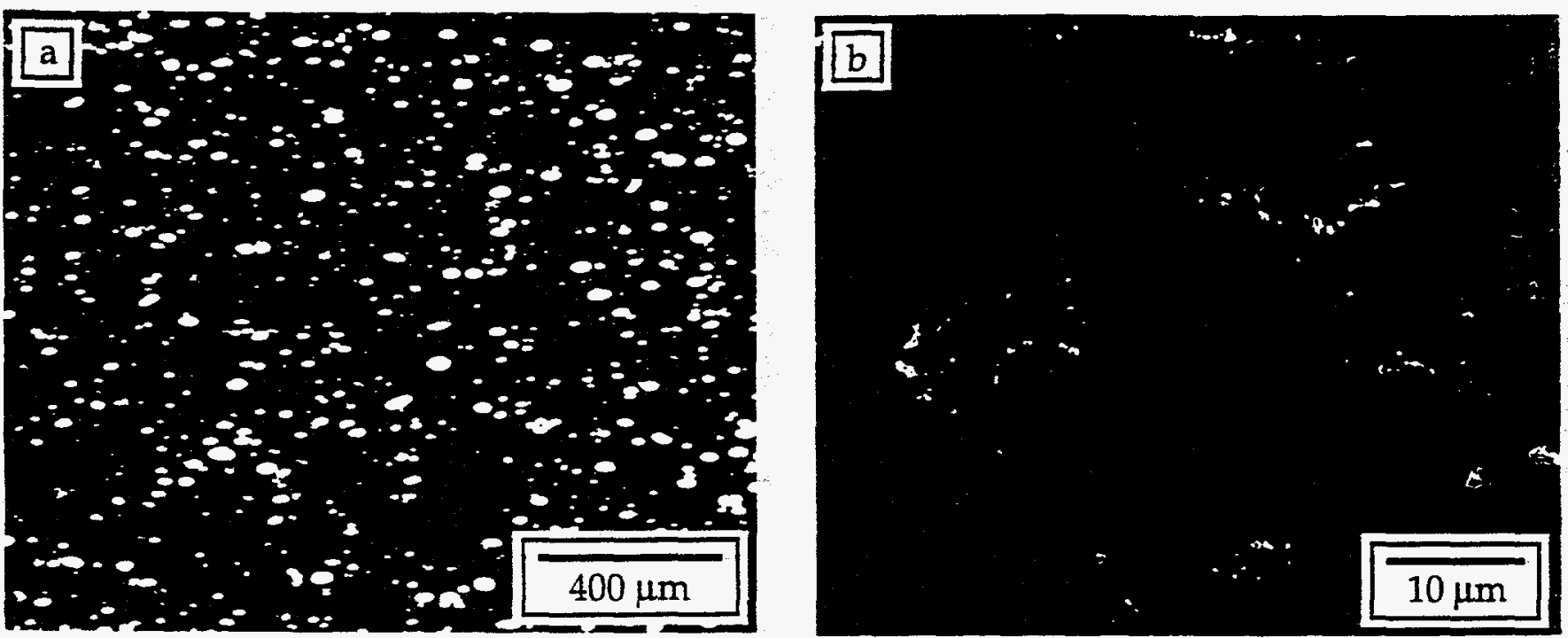

Figure 2 - (a) Optical image of isolated $\mathrm{Ni3} A \mathrm{Al}$ islands within an $\mathrm{Al}_{2} \mathrm{O}_{3}$ matrix (24). (b) SEM image showing semi-continuous $\mathrm{Ni}_{3} \mathrm{Al}$ grain boundary phase, with some isolated $\mathrm{Ni}_{3} \mathrm{Al}$ regions (WC matrix).

Room and elevated temperature $\left(800^{\circ} \mathrm{C}\right)$ fracture strengths of the cermets with an NizAl-based binder phase are shown in Figure 3, with a typical WC/Co material shown for comparison. Excellent strength retention is apparent for the $\mathrm{Ni} 3 \mathrm{Al}$ containing materials, with flexure strengths being almost invariant with temperature up to $800^{\circ} \mathrm{C}$. It is important to note that the yielding behavior of ordered $\mathrm{Ni}_{3} \mathrm{Al}$ is somewhat unusual, with yield stress increasing with temperature up to $-800^{\circ} \mathrm{C}(28)$. In comparison the WC/Co material, with a binder content of $\sim 17 \mathrm{vol}$. \%, shows a decrease in flexure strength of $\sim 32 \%$ (29). This behavior is particularly important for cutting applications, when tool contact temperatures can approach $1000^{\circ} \mathrm{C}$.

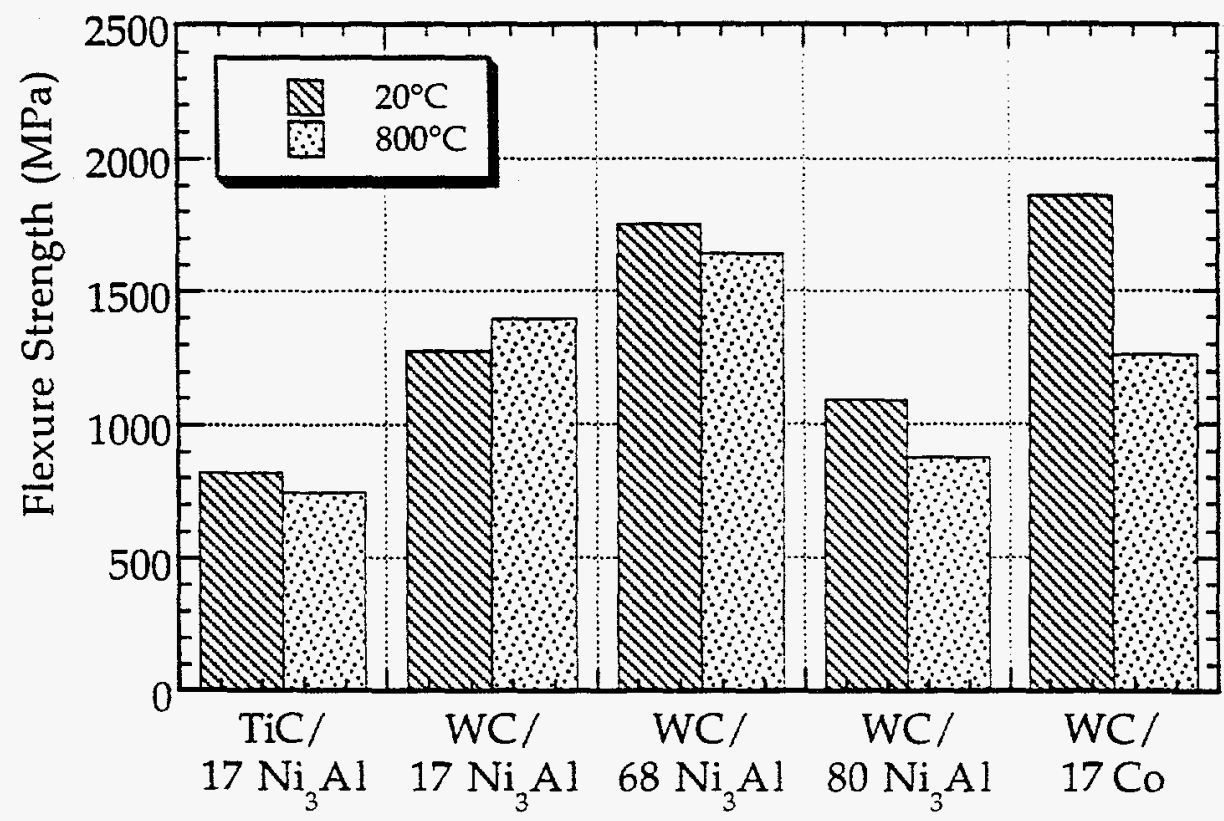

Figure 3 - Elevated flexure strengths for $\mathrm{WC}$ and $\mathrm{TiC}$ cermets prepared with an $\mathrm{Ni} 3 \mathrm{Al}$ binder phase (IC-50 alloy). Data for WC/Co is taken from reference 29. 
The lack of wetting in the pure $\mathrm{Al}_{2} \mathrm{O}_{3} / \mathrm{Ni}_{3} \mathrm{Al}$ system has led to the investigation of two revised processing routes for $\mathrm{Al}_{2} \mathrm{O}_{3}$ based matrices. The first utilizes the addition of 'wetting agents' to aid wetting during hot-pressing. Examples include $\mathrm{Al}_{2} \mathrm{O}_{3}-\mathrm{TiC}-\mathrm{Ni}_{3} \mathrm{Al}$ and $\mathrm{Al}_{2} \mathrm{O}_{3}-\mathrm{TiB}_{2}-\mathrm{Ni}_{3} \mathrm{Al}$. The second approach involves pressurized infiltration of a molten $\mathrm{Ni} 3 \mathrm{Al}$ melt into a porous, pre-sintered $\mathrm{Al}_{2} \mathrm{O}_{3}$ preform (relative density $\sim 60-65 \%$ of theoretical). An SEM micrograph of a $\mathrm{Al}_{2} \mathrm{O}_{3}-\mathrm{TiC}(25 \mathrm{vol} . \%)-\mathrm{Ni}_{3} \mathrm{Al}(10$ vol. \%) composite, hot-pressed at $1550^{\circ} \mathrm{C}$ for 90 minutes, is shown in Figure 4, which demonstrates the semicontinuous nature of the $\mathrm{Ni}_{3} \mathrm{Al}$ phase. A distinct core-rim structure is apparent, with the core comprising solely of $\mathrm{TiC}$ and the outer rim containing additional W, which is due to 'pick-up' during ball milling with WC media. The properties of these composites were generally similar to the $\mathrm{Al}_{2} \mathrm{O}_{3} / \mathrm{Ni}_{3} \mathrm{Al}(10$ vol. \%) materials, with slightly higher hardness (Microhardness, $\sim 18 \mathrm{GPa}$; flexure strength $350-580 \mathrm{MPa}$; fracture toughness $7-8 \mathrm{MPa} \cdot \mathrm{m}^{1 / 2}$ ). These materials exhibit a rising ' $\mathrm{R}$ ' curve behavior (Figure 5), due to combination of toughening mechanisms operating in the crack wake. It is apparent from Figure 5 that crack deflection, grain pull-out and ductile ligament bridging processes are occurring. Conversely, a fine grain sized $\mathrm{Al}_{2} \mathrm{O}_{3} / \mathrm{TiC}$ ceramic composite (which is shown for comparison) does not exhibit such toughening mechanisms (Figure 5).

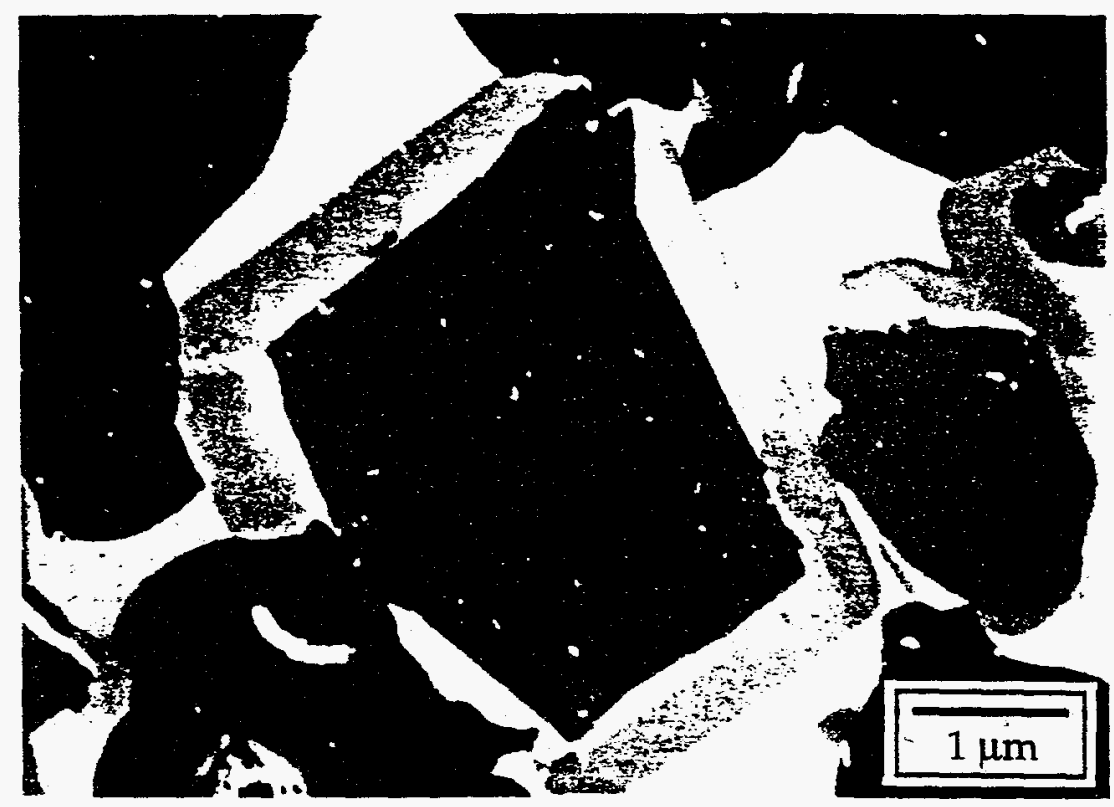

Figure 4 - Secondary electron SEM image of a $\mathrm{Al}_{2} \mathrm{O}_{3}-\mathrm{TiC}(25$ vol. \%)-Ni3 $\mathrm{Al}$ (10 vol. \%) cermet.
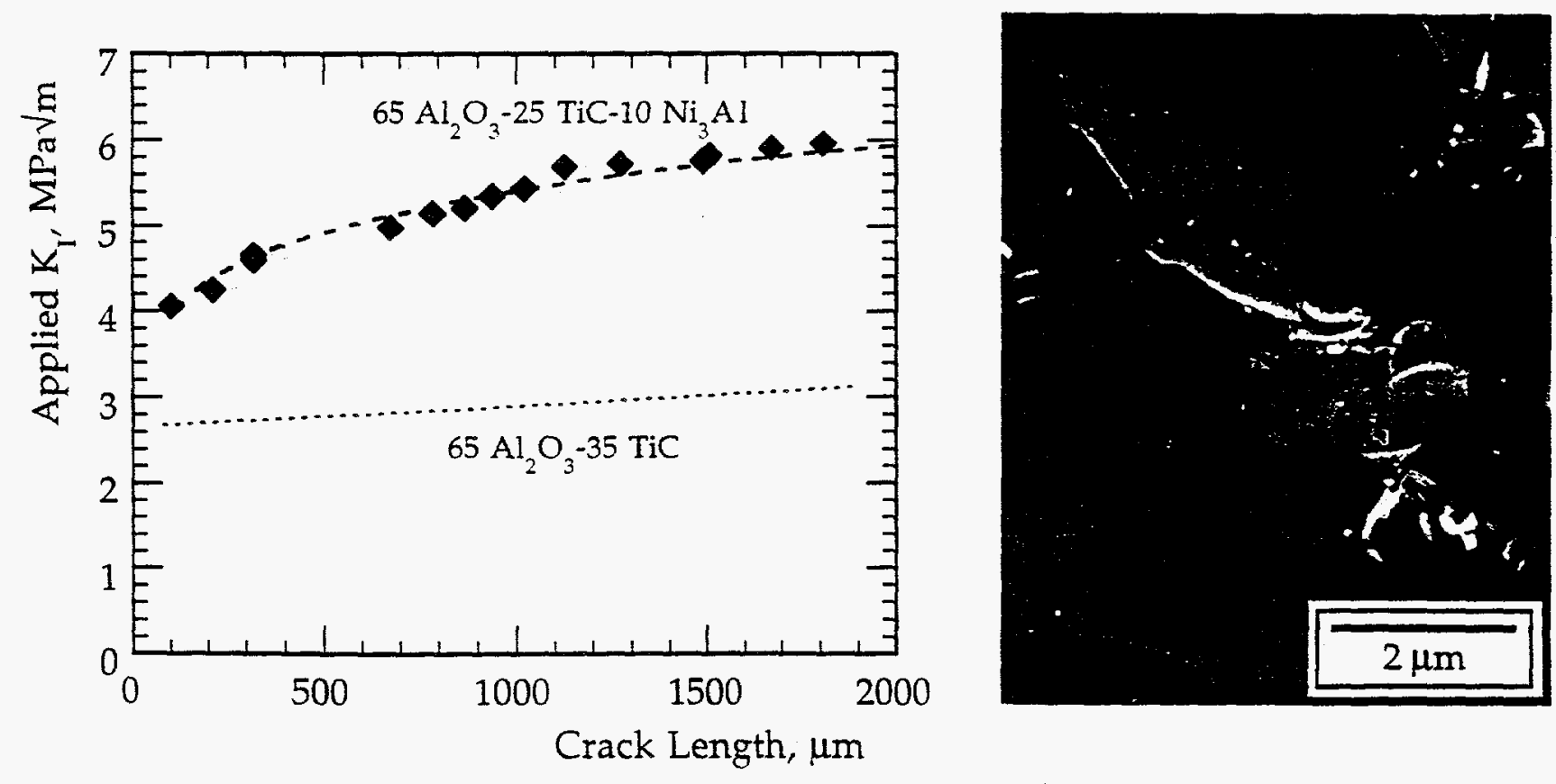

Figure 5 - ' $\mathrm{R}$ ' curve behavior of an $\mathrm{Al}_{2} \mathrm{O}_{3}-\mathrm{TiC}(25$ vol. \%)-Ni3 $\mathrm{Al}$ (10 vol. \%) cermet, with data obtained for a fine grain size $\mathrm{Al}_{2} \mathrm{O}_{3}$ ceramic shown for comparison. Inset demonstrates the crack path in the $\mathrm{Ni}_{3} \mathrm{Al}$ containing material (ductile bridging region arrowed). 
The infiltrated $\mathrm{Al}_{2} \mathrm{O}_{3} / \mathrm{Ni}_{3} \mathrm{Al}$ cermets possess a dual-phase interpenetrating microstructure (Figure 6), with approximately $35 \mathrm{vol} . \% \mathrm{Ni}_{3} \mathrm{Al}(14)$. These materials exhibit a rising ' $\mathrm{R}$ ' curve behavior (Figure 7). The primary toughening mechanism in these materials is believed to be crack wake bridging by the ductile $\mathrm{Ni}_{3} \mathrm{Al}$ ligaments, in a manner similar to that previously demonstrated for the $\mathrm{Al}_{2} \mathrm{O}_{3}-\mathrm{TiC}-\mathrm{Ni} 3 \mathrm{Al}$ material (shown in Figure 5). The effects of temperature upon both toughness and strength of these composites are shown in Table VI. It is apparent that the observed strength retention is similar to the WC/ $\mathrm{Ni}_{3} \mathrm{Al}$ cermets, with negligible degradation at the higher test temperature.

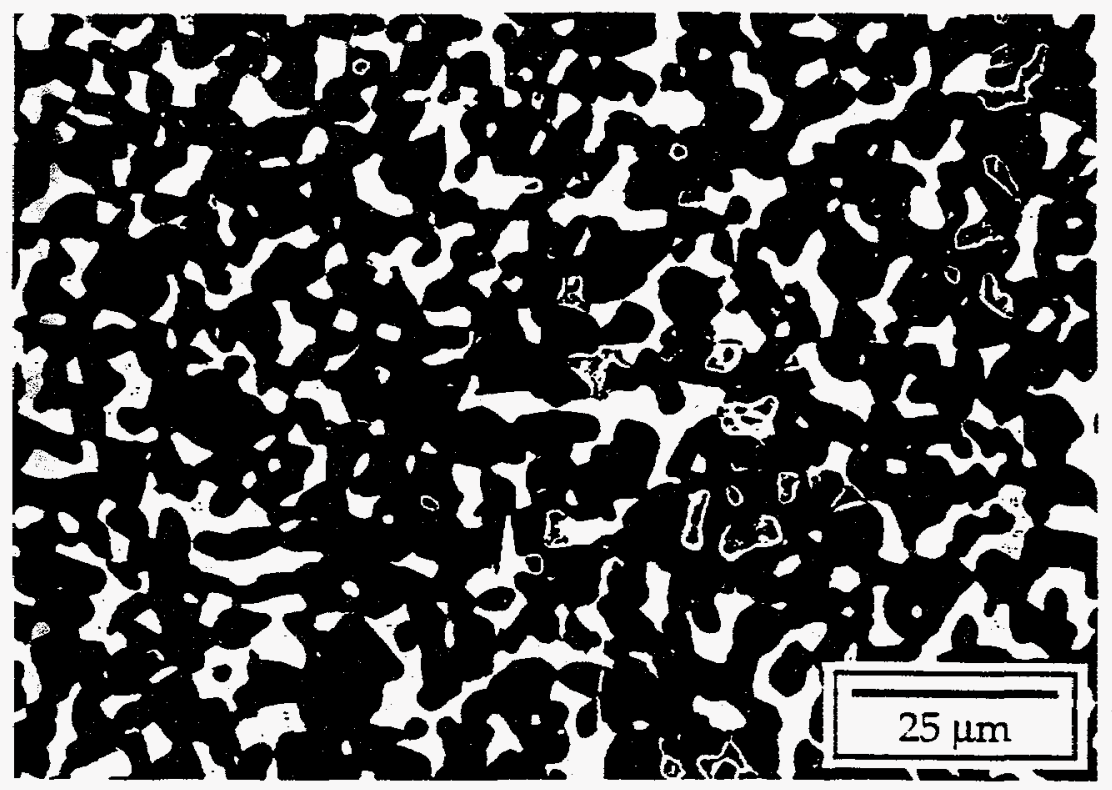

Figure 6 - SEM micrograph of the infiltrated $\mathrm{Al}_{2} \mathrm{O}_{3} / \mathrm{Ni}_{3} \mathrm{Al}$ cermet. Prepared by pressurized melt infiltration of $\mathrm{Ni}_{3} \mathrm{Al}$ into a pre-sintered $\mathrm{Al}_{2} \mathrm{O}_{3}$ preform.

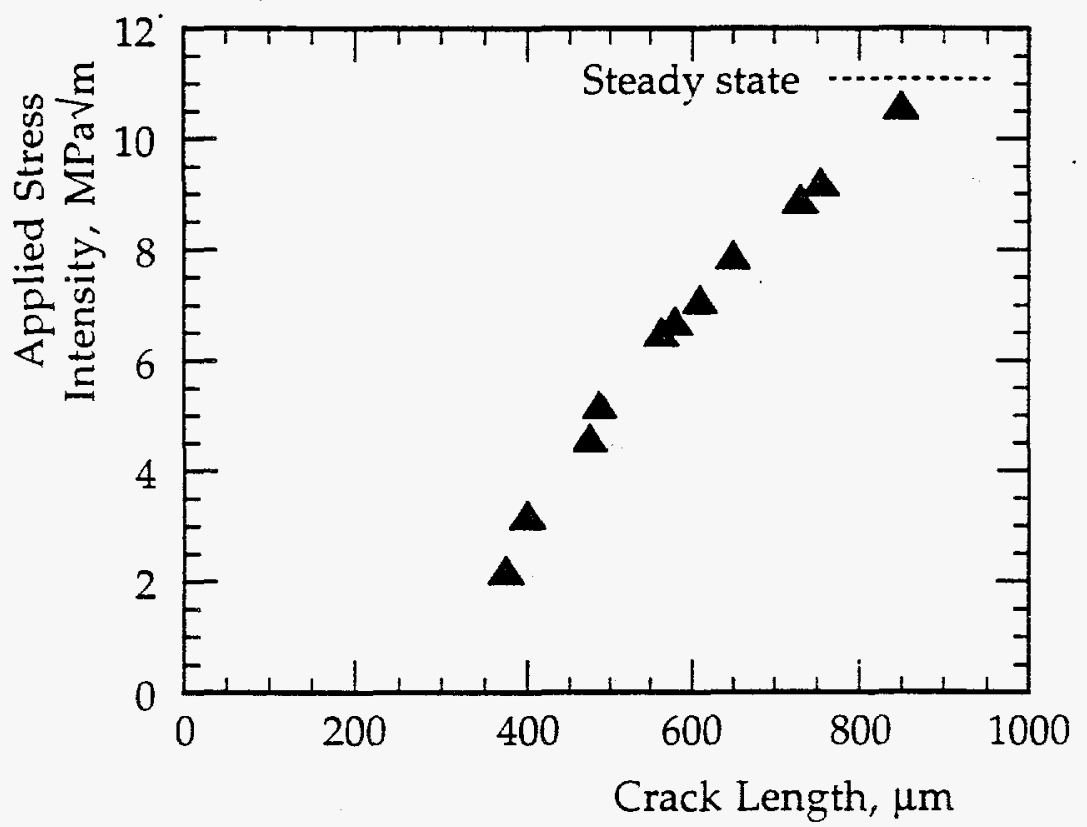

Figure 7 - ' $\mathrm{R}$ ' eurve for the $\mathrm{Al}_{2} \mathrm{O}_{3} / \mathrm{Ni}_{3} \mathrm{Al}$ composite shown in Figure 6, obtained by indent and in-situ fracture in the SEM.

One reason for the selection of $\mathrm{Ni}_{3} \mathrm{Al}$ binders as potential replacements for Co-based binders, is the superior corrosion resistance of $\mathrm{Ni}_{3} \mathrm{Al}$ over $\mathrm{Co}$. A series of preiliminary screening tests designed to assess the corrosion resistance of $\mathrm{WC} / \mathrm{Ni}_{3} \mathrm{Al}$ cermets has been performed, and comparison has been made to two commercial WC/Co materials (Figure 8). The Ni $3 \mathrm{Al}$-based materials show excellent resistance to corrosion by both nitric and sulfuric acids, in comparison to the commercial WC/Co hardmetals. It is also important to note that the volume percentage of the Co binder is also lower for the two commercial materials, emphasizing the improvement in corrosion resistance that can be attained by substitution of Co binders by NizAl. The effect of corrosion in hydrochloric acid appears to be similar for the two systems. A similar observation of improved resistance to corrosion has been noted when $\mathrm{Ni}$ is substituted for $\mathrm{Co}(4)$. 


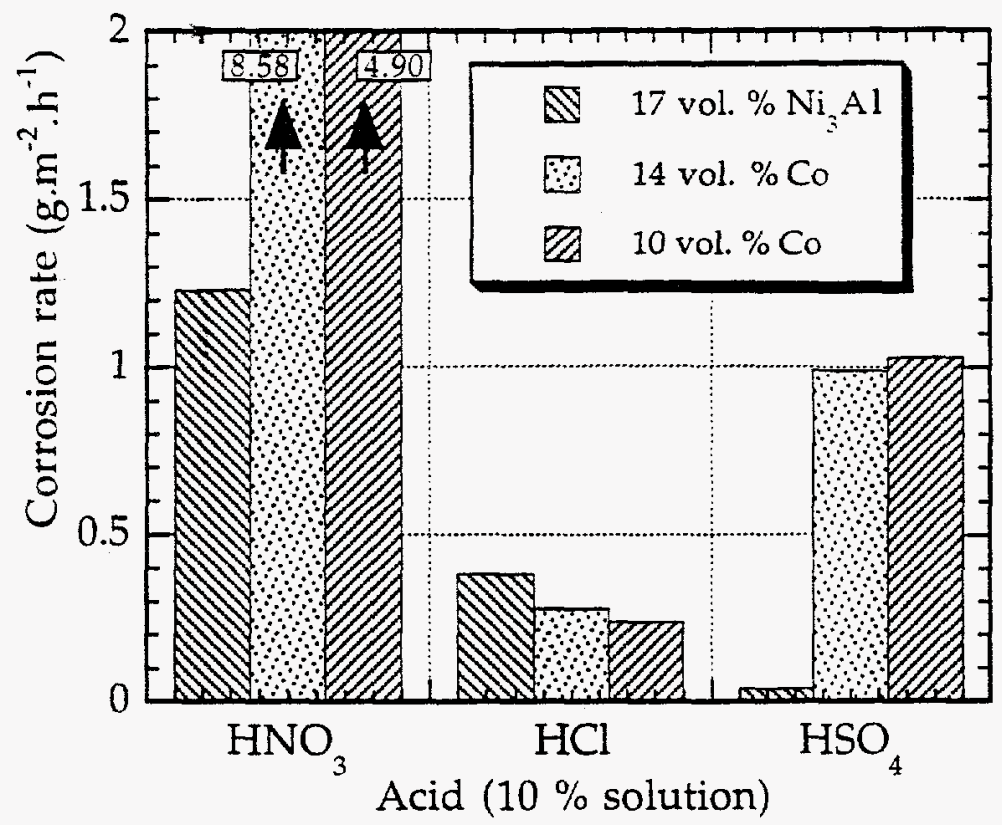

Figure 8 - Corrosion rates of a WC/Ni3 Al ( 17 vol. \%) cermet immersed in $10 \%$ acid solutions for 48 hours (at $25^{\circ} \mathrm{C}$ ). The WC/Co materials were commercial grade products.

Table VI - Fracture toughness (chevron notch) and flexure strength of $\mathrm{Ni}_{3} \mathrm{Al}$ infiltrated $\mathrm{Al}_{2} \mathrm{O}_{3}$, number of tests in parenthesis.

\begin{tabular}{lll}
\hline \hline $\begin{array}{l}\text { Test Temperature } \\
\left({ }^{\circ} \mathrm{C}\right)\end{array}$ & $\begin{array}{l}\text { Fracture Toughness } \\
\left(\mathrm{MPa} \cdot \mathrm{m}^{\mathrm{i} / 2}\right)\end{array}$ & $\begin{array}{l}\text { Flexure Strength } \\
(\mathrm{MPa})\end{array}$ \\
\hline 20 & $11.9 \pm 0.8(2)$ & $382 \pm 21(2)$ \\
800 (tested in argon) & $10.7 \pm 0.1(2)$ & $391 \pm 10(2)$ \\
\hline \hline
\end{tabular}

\section{CONCLUSIONS}

A range of carbide and oxide hardmetal/cermet materials have been prepared using ductile intermetallic binder phases based upon $\mathrm{Ni}_{3} \mathrm{Al}$. Dense materials can be prepared by uniaxial hot-pressing of powder mixtures or, in the case of $\mathrm{Al}_{2} \mathrm{O}_{3} / \mathrm{Ni}_{3} \mathrm{Al}$, by pressurized infiltration of a porous pre-sintered $\mathrm{Al}_{2} \mathrm{O}_{3}$ preform by molten $\mathrm{Ni}_{3} \mathrm{Al}$ alloys. Based upon the present study, the following conclusions can be drawn;

- From initial studies it is clear that $\mathrm{Ni} 3 \mathrm{Al}$ wets carbides such as WC and TiC extremely well, with low wetting angles $\left(<15^{\circ}\right)$. Conversely, oxides such as $\mathrm{Al}_{2} \mathrm{O}_{3}$ are not wetted by $\mathrm{Ni}_{3} \mathrm{Al}$ to any great extent, with wetting angles typically $>70^{\circ}$. The lack of wetting in the 'pure' oxide systems results in the formation of isolated regions of $\mathrm{Ni}_{3} \mathrm{Al}$ in hot pressed materials.

- High density WC cermets have been produced with varying amounts of $\mathrm{Ni}_{3} \mathrm{Al}$ binder phase. These materials have been shown to exhibit four point bend fracture strengths approaching $2 \mathrm{GPa}$, with indent toughness values up to $25 \mathrm{MPa} \cdot \mathrm{m}^{1 / 2}$ and a hardness of $7 \mathrm{GPa}$, when high binder contents are used (i.e. $\sim 68$ vol. \%). When the $\mathrm{Ni}_{3} \mathrm{Al}$ binder content is similar to conventional WC/Co hardmetals (i.e. $\sim 17$ vol. \%), the flexure strengths are between 1.2 to $1.4 \mathrm{GPa}$, with toughness values between $10-20$ $\mathrm{MPa} . \mathrm{m}^{1 / 2}$ and hardnesses of the order of 14 to $18 \mathrm{GPa}$. Properties for the hot-pressed TiC/Ni3 $\mathrm{Al}$ cermets were generally inferior to the WC based materials, with the exception of hardness which was improved slightly.

- The WC/Ni3Al based materials exhibited excellent property retention at temperatures up to $800^{\circ} \mathrm{C}$. with flexure strength values similar to those obtained at room temperature. These observations compare 
favorably to those for $\mathrm{WC} / \mathrm{Co}$, where flexure strength is typically reduced by $30-40 \%$ when testing at $800^{\circ} \mathrm{C}$.

- The lack of wetting in the hot-pressed $\mathrm{Al}_{2} \mathrm{O}_{3} / \mathrm{Ni}_{3} \mathrm{Al}$ system has led to two approaches to overcome this problem. The first has involved the addition of a 'wetting' phase, namely $\mathrm{TiC}$, to the powder mixture. This leads to the retention of an interpenetrating microstructure after hot-pressing. However, to date the resulting properties of these composites are inferior to the simpler carbide/aluminide materials (i.e. $\mathrm{WC} / \mathrm{Ni}_{3} \mathrm{Al}$ ). The second approach is based upon the use of pressure infiltration of a molten $\mathrm{Ni}_{3} \mathrm{Al}$ melt into a pre-sintered $\mathrm{Al}_{2} \mathrm{O}_{3}$ preform. This results in a dual phase, interpenetrating microstructure, which exhibits a steeply rising ' $\mathrm{R}$ ' curve behavior, and high toughness. Flexure strengths are relatively low however, due to a weak interface between the $\mathrm{Al}_{2} \mathrm{O}_{3}$ and $\mathrm{Ni}_{3} \mathrm{Al}$.

- WC cermets, based upon the use of $\mathrm{Ni}_{3} \mathrm{Al}$ binder phases, show considerably improved resistance to corrosion in both nitric and sulfuric acid when compared to conventional materials prepared with Co. Resistance to corrosion by hydrochloric acid is similar for the two binder phases.

\section{ACKNOWLEDGMENTS}

The authors thank Drs. Chun-Hway Hsueh and Ellen Sun for review of the manuscript. Drs. Nils Claussen and Jürgen Rödel are gratefully acknowledged for provision of the $\mathrm{Ni}_{3} \mathrm{Al}$ infiltrated $\mathrm{Al}_{2} \mathrm{O}_{3}$ sample. Research sponsored by the U.S. Department of Energy, Assistant Secretary for Energy Efficiency and Renewable Energy, Office of Industrial Technologies, Advanced Industrial Materials Program, under contract DE-AC05-84OR21400 with Martin Marietta Energy Systems, Inc. KPP is also supported by an appointment to the ORNL Postdoctoral Research Program administered by the Oak Ridge Institute for Science and Technology.

\section{REFERENCES}

1. P. Schwartzkopf and R. Kieffer, Cemented Carbides, Macmillan Co., New York, U.S.A., 1960.

2. P. Ettmayer, "Hardmetals and Cermets", Annual Review of Materials Science, Vol. 19, 1989, 145164.

3. B. Roebuck and A.E. Almond, "Deformation and Fracture Processes and the Physical Metallurgy of WC-Co Hardmetals", International Materials Reviews, Vol. 33, No. 2, 1988, 90-110.

4. $\quad$ R.W. Stevenson, "Cemented Carbides", ASM Handbook, Vol. 7, 1984, 773-783.

5. L.S. Sigl and H.E. Exner, "Experimental Study of the Mechanics of Fracture in WC-Co Alloys", Metallurgical Transactions A, Vol. 18A, 1987, 1299-1308.

6. L.S. Sigl and H.F. Fischmeister, "On the Fracture Toughness of Cemented Carbides", Acta Metallurgica, Vol. 36, No. 4, 1988, 887-897.

7. K.S. Ravichandran, "Fracture Toughness of Two Phase WC-Co Cermets", Acta Metallurgica et Materialia, Vol. 42, No. 1, 1994, 143-150.

8. H. Holleck, "Constitutional Aspects in the Development of New Hard Materials", Science of Hard Materials, R.K. Viswanadham, D.J. Rowcliffe and J. Gurland, Eds., Plenum Press, New York, NY, USA, $1981,849-858$.

9. L. Prakash, H. Holleck, F. Thümmler and G.E. Spriggs, "WC Cemented Carbides with Improved Binder Alloys", Towards Improved Performance of Tool Materials, R.S. Irani, E.A. Almond and F.A. Kirk, Eds., The Metals Society, London, 1982, 118-121.

10. R.K. Viswanadham, P.G. Lindquist and J.A. Peck, "Preparation and Properties of WC-(Ni,Al) Cemented Carbides", Science of Hard Materials, R.K. Viswanadham, D.J. Rowcliffe and J. Gurland, Eds., Plenum Press, New York, NY, USA, 1981, 873-885. 
11. T. Farooq and T.J. Davies, "Preparation of Some New Tungsten Carbide Hardmetals", $\underline{\text { Powder }}$ Metallurgy International, Vol. 22, No. 4. 1990, 12-16.

12. T. Farooq and T.J. Davies, "Tungsten Carbide Hard Metals Cemented with Ferroalloys", The International Journal of Powder Metallurgy. Vol. 27, No. 4, 1991, 347-355.

13. K.P. Plucknett, T.N. Tiegs and P.F. Becher, unpublished research, Oak Ridge National Laboratory, 1995.

14. N. Claussen, M. Knechtel, H. Prielipp and J. Rödel, "Metcers- A Strong Variant of Cermets", CFI, Vol. 71, No. 6, 1994, 301-304.

15. G.R. Antis, P. Chantikul, B.R. Lawn and D.B. Marshall, "A Critical Evaluation of Indentation Techniques for Measuring Fracture Toughness: I, Direct Crack Measurements", Journal of the American Ceramic Society, Vol. 64, No. 9, 1981, 533-538.

16. P. Chantikul, G.R. Antis, B.R. Lawn and D.B. Marshall, "A Critical Evaluation of Indentation Techniques for Measuring Fracture Toughness: II, Strength Method", Journal of the American Ceramic Society, Vol. 64, No. 9, 1981, 539-543.

17. B. Mei, R. Yuan and X. Duan, "Investigation of Ni3Al-Matrix Composite Strengthened by TiC", Journal of Materials Research, Vol. 8, No. 11, 1993, 2830-2834.

18. X. Liang, H.K. Kim, J.C. Earthman and E.J. Lavernia, "Microstructure and Elevated Temperature Behavior of a Spray-Atomized and Co-Deposited $\mathrm{Ni}_{3} \mathrm{~A} 1 / \mathrm{SiC} / \mathrm{TiB}_{2}$ Intermetallic Matrix Composite", Materials Science and Engineering. Vol. A153, 1992, 646-653.

19. X. Liang and E.J. Lavernia, "Interfacial Behavior in a $\mathrm{Ni}_{3} \mathrm{Al} / \mathrm{TiB}_{2}$ Intermetallic Matrix Composite", Materials Science and Engineering, Vol. A153, 1992, 654-661.

20. G.L. Povirk, J.A: Horton, C.G. McKamey, T.N. Tiegs and S.R. Nutt, "Interfaces in Nickel Aluminide/Alumina Fiber Composites", Journal of Materials Science, Vol. 23, 1988, 3945-3950.

21. P.C. Brennan, W.H. Kao and J.-M. Yang, "The Mechanical Properties of an $\mathrm{Al}_{2} \mathrm{O}_{3} / \mathrm{Ni}_{3} \mathrm{Al}$ Particulate-reinforced Composite", Materials Science and Engineering, A, Vol. A153, 1992, 635-640.

22. S. Nourbakhsh, W.H. Rhee, O. Sahin and H. Margolin, "Mechanical Behavior of a Fiber Reinforced Ni3Al Matrix Composite", Materials Science and Engineering, A, Vol. A153, 1992, 619-627.

23. S. Nourbakhsh, W.H. Rhee, O. Sahin and H. Margolin, "Oxidation Behavior of Single-Crystal $\mathrm{Al}_{2} \mathrm{O}_{3}$-Fiber-Reinforced $\mathrm{Ni}_{3} \mathrm{Al}$-Based Composites", Metallurgical and Materials Transactions A, Vol. 25A, 1994, 1501-1507.

24. K.B. Alexander, J.H. Schneibel, H.-T. Lin and P.F. Becher, The Fabrication and Processing of Alumina Composites Containing Nickel Aluminide", Processing and Fabrication of Advanced Materials for High Temperature Applications III, V.A. Ravi, T.S. Srinivatsan and J.J. Moore, Eds., TMS, Warrendale, PA, USA, 1994.

25. S. Ochiai, Y. Oya and T. Suzuki, "Alloying Behavior of $\mathrm{Ni}_{3} \mathrm{Al}, \mathrm{Ni}{ }_{3} \mathrm{Ga}, \mathrm{Ni}_{3} \mathrm{Si}$ and $\mathrm{Ni}_{3} \mathrm{Ge}$, $\underline{\mathrm{Acta}}$ Metallurgica, Vol. 32, No. 2, 1984, 289-298.

26. C.T. Liu and J.O. Stiegler, "Ordered Intermetallics", ASM Handbook, Vol. 2, ASM International, $1990,913-942$.

27. R. Warren and B. Johannesson, "The Fracture Toughness of Hardmetals", International Journal of Refractory and Hard Materials, Vol. 3, No. 4, 1984, 187-191.

28. F.E. Heredia and D.P. Pope, "The Plastic Flow of Binary Ni3 Al Single Crystals", Acta Metallurgica et Materialia, Vol. 39, No. 8, 1991, 2027-2036.

29. G.S. Kreimer, Strength of Hard Alloys, Consultants Bureau. Plenum Press, New York, 1968. 